ISSN: 2302-8556

E-Jurnal Akuntansi Universitas Udayana

Vol.23.3.Juni (2018): 2175-2202

DOI: https://doi.org/10.24843/EJA.2018.v23.i03.p21

\title{
Pengaruh Pengalaman Audit, Pengetahuan Mendeteksi Kekeliruan, Independensi Dan Audit Tenure Pada Audit Judgment
}

\author{
Made Ayu Oktaviana ${ }^{1}$ \\ Maria Mediatrix Ratna Sari ${ }^{2}$
}

${ }^{1}$ Fakultas Ekonomi dan Bisnis Universitas Udayana (Unud), Bali, Indonesia
email: ayuoktaviana_shandy@yahoo.com/telp:087861754998
${ }^{2}$ Fakultas Ekonomi dan Bisnis Universitas Udayana (Unud), Bali, Indonesia

\begin{abstract}
ABSTRAK
Tujuan penelitian ini untuk mendapatkan bukti empiris tentang pengaruh pengalaman audit, pengetahuan mendeteksi kekeliruan, independensi dan audit tenure pada audit judgment. Penelitian ini dilaksanakan pada Kantor Akuntan Publik di wilayah Bali dan terdaftar dalam IAPI tahun 2017 dengan metode pengumpulan data primer yaitu kuesioner. Jumlah sampel yang dianalisis sebanyak 44 responden, dan menggunakan metode penelitian purposive sampling. Teknik analisis yang digunakan adalah Analisis Regresi Linear Berganda. Hasil akhir penelitian menyatakan bahwa semakin tinggi pengalaman audit maka audit judgment semakin akurat. Semakin meningkat pengetahuan mendeteksi kekeliruan seorang auditor maka audit judgment semakin akurat. Semakin tinggi independensi seorang auditor maka audit judgment semakin akurat. Semakin meningkat audit tenure seorang auditor maka audit judgment semakin akurat.
\end{abstract}

Kata kunci : Pengalaman audit, pengetahuan mendeteksi kekeliruan, independensi, audit tenure, audit judgment

\section{ABSTRACT}

The purpose of this research was to obtain empirical evidence on the influence of audit experience, knowledge of detecting errors, independence and audit tenure on audit judgment. This research was conducted at Public Accountant Office in Bali area and registered in IAPI year 2017 with primary data collection method that is questioner. The number of samples analyzed by 44 respondents, and using purposive sampling method. The analysis technique used is Multiple Linear Regression Analysis. The final result of the research states that the higher the audit experience the more accurate audit judgment. Increasing the knowledge detecting errors an auditer so audit judgment is more accurate. The higher the independence of an auditor the audit judgment is more accurate. The more audit tenure an auditer the audit judgment more accurate.

Keywords : Audit experience, knowledge of detecting errors, independence, audit tenure, audit judgment 


\section{PENDAHULUAN}

Pelaku bisinis semakin banyak ingin mengembangkan berbagai macam usaha yang disebabkan pesatnya perkembangan dunia bisnis akibat persaingan dunia usaha semakin meningkat. Hasil usaha dan kondisi keuangan suatu perusahaan merupakan gambaran laporan keuangan. Laporan keuangan menjadi sumber informasi keuangan yang sangat dibutuhkan untuk pengambilan keputusan bisnis dan sebagai indikator pengukuran kinerja perusahaan. Karena itulah, laporan keuangan menjadi indikator penting.

Akuntan Publik yang merupakan pihak independen, diandalkan perusahaan untuk kebijakan pemeriksaan laporan keuangan. Keahlian seseorang yang dimilikinya dalam bidang akuntansi yakni melakukan kegiatan pemeriksaan laporan keuangan untuk mengetahui adanya salah saji material dalam laporan keuangan disebut sebagai auditor. Pribadi auditor yang dapat mempertahankan integritasnya yakni melaksanakan tugas dengan jujur dan bekerja tanpa tekanan pihak tertentu (Mayasari,2011). Auditor memiliki tugas utama yakni melakukan tugas audit dan

memberikan opininya yang didasarkan pendidikan, pengalaman, sikap profesionalisme serta harus berpedoman pada peraturan yang ada.

Pertimbangan yang mempengaruhi bukti serta keputusan pendapat auditor adalah audit judgment. Dikumpulnya bukti-bukti pada waktu yang berbeda kemudian mengintegrasikannya informasi dari bukti-bukti tersebut merupakan audit judgment yang dibuat oleh auditor (Nadiroh, 2010). Cara pandang seorang auditor saat menanggapi informasi-informasi yang berhubungan dengan tanggungjawab resiko 
ISSN: 2302-8556

audit yang akan dia hadapi dan mampu mempengaruhi opini audit yang akan dibuat pada laporan keuangan entitas merupakan judgment yang dibuat oleh auditor (Pranoto, 2013). Karena inilah dengan kata lain audit judgment ikut serta dalam ditentukannya hasil audit.

Hasil akhir dari judgment akan dapat dipengaruhi oleh setiap langkah dalam proses judgment, karena proses judgment tergantung dari asal informasi. Oleh karena itu, ketika auditor memberikan opini atas kewajaran laporan keuangan maka auditor harus mampu mempertimbangkan dan memutuskan dengan pasti seberapa jauh nilai akuratnya dan keabsahan dari bukti yang diperoleh serta informasi yang diberikan oleh klien (Tielman, 2012).

Adanya berbagai kasus kegagalan audit sebagai contoh, salah satunya di Indonesia yaitu PT. Kimia Farma adalah salah satu produsen obat-obatan milik pemerintah di Indonesia. Pada tanggal 31 Desember 2001, manajemen Kimia Farma melaporkan adanya laba bersih sebesar Rp 132 milyar yang dilaksanakan pengauditan oleh Hans Tuanakotta \& Mustofa. Namun, Kementrian BUMN dan Bapepam menilai terkandungnya unsur rekayasa dan terlalu besarnya laba bersih. Setelah melakukan audit ulang ternyata ditemukan kesalahan. Kesalahan penyajian tersebut merupakan daftar harga persediaan digelembungkan dan adanya pencatatan ganda atas penjualan. Dilakukannya pencatatan ganda atas unit yang tidak disamplingnya oleh akuntan mengakibatkannya gagalnya mendeteksi adanya kecurangan. Penyelidikan yang dilakukan Bapepam menyatakan bahwa KAP yang melakukan pemeriksaan laporan keuangan PT.Kimia Farma sudah sesuai dengan standar audit 
yang berlaku, tetapi masih saja melakukan kegagalan dalam mengetahui adanya kecurangan yang terjadi (https://davidparsaoran.wordpress.com). Dari kasus tersebut KAP yang mengaudit laporan keuangan PT.Kimia Farma dan auditor HTM dinyatakan tidak mampu mengatasi adanya resiko audit dalam mendeteksi pada kecurangan dan kekeliruan yang terjadi yaitu terjadinya penggelembungan laba yang dilakukan oleh PT.Kimia Farma.

Selain itu, contoh kasus lainnya yaitu Enron Corporation merupakan salah satu perusahaan terkemuka di Amerika Serikat dengan bisnis yang bergerak dalam bidang listrik, gas alam, bubur kertas dan kertas, serta komunikasi. Kemudian pada bulan Desember 2001 Enron terkena kasus yang disebabkan oleh manajemen Enron yang telah dimanipulasikannya angka-angka laporan keuangan supaya terlihat kinerjanya bagus. Auditor Enron, Arthur Andersen disalahkan dikarenakan ikutmembantu proses rekayasa keuangan itu. Kegiatan manipulasi ini diakibatkannya hutang hampir sebesar US\$ 31,2 milyar. Oleh karena inilah, terjadi turunnya dengan drastis harga saham dari berbagai bursa efek dibelahan dunia. Keadaan turunnya harga saham di berbagai bursa efek ini dirasakan oleh negara Amerika, Eropa samapi ke Asia (https://nurulirmawati.wordpress.com).

Mengenai kasus Enron Corporation dan KAP Arthur Andersen mencerminkan bahwa independensi auditor semakin menurun. Keadaan ini akan berdampak tidak baik pada citra profesi akuntan publik KAP Andersen dimata masyarakat dan pihak lainnya. Dengan demikian menyebabkan ketidak percayaan entitas terhadap auditor dan menimbulkan skeptisisme entitas memilih akuntan publik. 
ISSN: 2302-8556

Adapun contoh kasus lainnya yaitu terjadi skandal keuangan pada Olympus Corporation yang merupakan sebuah peusahaan produsen kamera dan peralatan kesehatan asal Jepang, yang terungkap pada akhir tahun 2011. Olympus Corporation telah menyembunyikan kerugian dengan dianggapnya sebagai asset sejak tahun 1990an (https://lauraneviyanti.wordpress.com). Mengenai kasus Olympus Corporation, terjadi kegagalan auditor dalam mendeteksimaupun mengungkapkan adanya kecurangan padalaporan keuangan Olympus Corporation. Hal ini dikarenakan auditor tidak melaksanakan tugasnya dengan baik serta tidak cukup kompeten dan independen dalam mengaudit laporan keuangan.

Beberapa kasus kegagalan audit yang telah dipaparkan diatas ditimbulkannya krisis kepercayaan masyarakat pada akuntan yang tidakmampu mengaudit laporan keuangan. Adapun alasan kemunculan krisis ini, dikarenakan cukup banyak laporan keuangan perusahaan yang mendapat opini wajar tanpa pengecualian, tetapi setelah opini dikeluarkan justru terjadinya kebangkrutan (Seni Fitriani dan Daljono,2012). Kasus gagal audit dapat berdampak buruk dimasa depan. Seperti halnya terkena kasus hukum atau tuntutan hukum, hilangnya profesionalisme, hilangnya kepercayaan masyarakat dan kredibilitas sosial serta terancamannya reputasi auditor. Kunci utama dalam mempertahankan reputasi dengan melakukan pencegahan terhadap terjadinya kasus gagal audit.

Mencegah terjadinya kasus gagal audit, auditor harus memiliki sikap profesionalisme. Sikap profesionalisme auditor dapat tercermin oleh ketepatan auditor dalam membuat judgment atas tugas auditnya (Seni Fitriani dan Daljono, 
2012). Auditor harus bersikap profesionalisme dan dijunjung tinggi kode etikprofesi serta standar audit yangharus menjadikan pedoman dalam melaksanakan pekerjaannya sebagai profesi yang bertanggungjwab atas opini dalam laporan keuangan yang diauditnya. Professional judgment harus dilibatkan dalam tahap pekerjaan audit. Karena itulah, sikap profesionalnya nantinya akan membuat auditor dapat menghadapi munculnya tekanan dari pihak luar maupun pada dalam dirinya.

Pada Standar Profesi Akuntan Publik (SPAP), pertimbangan profesional wajib dilakukan oleh auditor untuk menilai hal yang terkait dengan audit. Karena itulah, audit judgment menjadi penting untuk diteliti. Oleh sebab itu judgment dalam auditing merupakan suatu proses yang penting dan tidak dapat dilepaskan dalam auditing (Seni Fitriani dan Daljono,2012). Semakin akurat audit judgment maka hal inilah menyebabkan hasil audit semakin akurat. Karena inilah judgment auditor yaitu sangat tergantungnya dari persepsi seseorang padasuatu situasi dan sebagai sebuah pertimbangan subyektifnya (Lopa, 2014). Dengan terdapatnya peran penting auditor untuk menilai laporan keuangan, jadi sangat dibutuhkan untuk diketahuinya faktor apasaja yang terpengaruhinya auditor pada pembuatan audit judgment.

Faktor non teknis ataupun teknis dapat memengaruhi audit judgment. Faktor non teknisnya yaitu seperti aspek perilaku individu yang dinilai dapat memengaruhi audit judgment. Sedangkan faktor teknis yang dimaksud yaitu seperti adanya suatu pembatasan lingkup atau adanya waktu audit. Adapun faktor yang digunakan dalam penelitian ini adalah pengalaman audit. Pengalaman adalah kemampuan yang dimiliki auditor untuk belajar dari kejadian-kejadian masa lalu yang berhubungan dengan 
ISSN: 2302-8556

seluk-beluk audit atau pemeriksaan Ashton (dalam Sucipto, 2007). Saat mengambil keputusan, pengalaman auditor akan menjadi sebuah pertimbangan yang baik. Melalui pengalamannya, auditor akan mampu belajar aktif dan menjalani tugasnya dengan baik sehingga dapat menunjang pemberian judgment yang akurat. Pernyataan tersebut telah dilakukan oleh Putri (2015), Reni Yendrawati (2015) dan Tielman (2012).

Selain pengalaman audit, faktor yang digunakan dalam penelitian ini adalah pengetahuan mendeteksi kekeliruan. Pengetahuan merupakan salah satu kunci keefektifan kerja (Arleen,2009). Tingginya tingkat pengetahuan yang dimiliki auditor, selain dapat diselesaikannya suatu tugas audit dengan efektif. Tentu saja akan memiliki pandangan yang lebih luas dalam berbagai hal, salah satunya pengetahuan mendeteksi kekeliruan. Auditor dapat semakin memahami bermacam masalah secara mendalam dengan semakin banyakknya pengetahuan yang dimiliki oleh auditor dalam bidang yang digelutinya. Hal ini dikarenakan dalam pembuatan audit judgment dan melakukan pertimbangan objektif dalam menyatakan suatu pendapatnya, seorang auditor harus memiliki pengetahuan mendeteksi kekeliruan.Pernyataan tersebut didukung oleh penelitian Seni Fitriani (2012), Arleen Herawaty (2009), Desiana (2012), dan Christanti (2016).

Independensi merupakan faktor penting bagi auditor untuk menghasilkan judgment. Independensi merupakan saat mempertimbangkan fakta dan saat diberikannya opini audit atas sikap seseorang yang tidak mudah dipengaruhi pihak lain, secara intelektual bersikap jujur dan objektif (Mulyadi, 2008:26). Independensi 
yang tinggi pada auditor maka kinerjanya akan lebih baik dan tepat sehingga menghasilkan audit judgment yang akurat, hal ini disebabkan auditor bekerja tanpa ada pengaruh dan tekanan dari pihak manapun sehingga informasi yang diperoleh sesuai dengan fakta. Pernyataan tersebut didukung oleh penelitian Handani (2014), Mukhlis (2010), dan Julia (2015).

Faktor lain yang mempengaruhi audit judgment yaitu, audit tenure. Audit tenure adalah diberikannya jasa audit atas lama masa perikatan Kantor Akuntan Publik pada klien (Maharani,2014). Audit tenure adalah faktor yang mempengaruhi kinerja seseorang (Sofiani dan Tjondro,2014). Audit tenure, yakni dikondisikannya batasan dan anggaran waktu untuk auditor pada pengauditan. Elemen penting mekanisme operasional dan kontrol pada suatu KAP yaitu anggaran waktu audit.Oleh karena itu, setiap KAP harus dapat mengalokasikan waktu secara tepat. Apabila KAP tidak bisa mengalokasikan waktu,maka berdampak pada biayaaudit yang semakin besar dan efektifitas pelaksanaan audit. Hal ini kemungkinan KAP akan kehilangan klien karena tingginya biaya audit dan waktu pelaksanaan audit yang terlalu lama. Selain hal itu yang dapat mempengaruhi judgment auditor yakni auditor kerap kali bekerja dalam keterbatasan waktu.

Keberadaan tekanan waktu ini menekan auditor untuk menyelesaikan tugas secepatnya dengan waktu tugas sangat sedikit dan tidak seimbang dengan tugas yang harus ditangani maka dapat memicu auditor bertindak tidak etis atau disfungsional. Oleh sebab itu, dalam setiap penugasan yang diberikan seorang auditor telah dialokasikan waktu yang sesuai atas kompleksitasnya tugas. Oleh karena itu, 
ISSN: 2302-8556

seharusnya auditor mampu menjalankan pekerjaan yang diberikan dengan mudah. Adanya waktu penyelesaian audit yang ketat diharapkan menjadi stimulus sehingga diharapkan auditor merespon tekanan waktu audit dengan baik dan termotivasi agar bersikap fokus menyelesaikan tugasnya tepat waktu dan menghasilkan laopranaudit yang berkualitas. Penelitian audit tenure didukung oleh penelitian dari (Sofiani dan Tjondro, 2014) dan (Syahrin,2016).

Penelitian ini dimotivasi oleh penelitian yang dilakukan oleh Syahrin (2016) dengan judul “ Pengaruh Tekanan Ketaatan, Pengalaman Audit, Gender, dan Audit Tenure Terhadap Audit Judgment". Perbedaan penelitian ini dengan penelitian sebelumnya adalah variabel yang digunakan, pada penelitian ini ada penambahan variabel pengetahuan mendeteksi kekeliruan dan independensi serta penghapusan variabel tekanan ketaatan dan gender. Hasil penelitian menunjukkan bahwa tekanan ketaatan, pengalaman audit, gender, dan audit tenure berpengaruh terhadap audit judgment yang diambil oleh auditor. Perbedaan lainnya juga dikarenakan terdapat perbedaan yang terletak pada dimensi waktu dan tempat. Perbedaan dimensi waktu yang dimaksud adalah penelitian ini dilaksanakan pada tahun 2017. Hal ini dikarenakan situasi dan kondisi yang menyebabkan persepsi responden yang berbeda. Sedangkan perbedaan dimensi tempat yang dimaksud dimana penelitian sebelumnya melakukan penelitian di KAP wilayah Jakarta Barat sedangkan dalam penelitian ini dilakukan di KAP wilayah Bali. Dengan adanya perbedaan tempat berarti terdapat perbedaan budaya yang berkembang pada masing-masing wilayah sehingga akan 
memengaruhi cara berfikir dan cara pandang dari satu kelompok sosial dengan kelompok sosial yang lain.

Penggunaan variabel pengalaman audit, pengetahuan mendeteksi kekeliruan, independensi, dan audit tenure dalam penelitian ini menarik untuk diteliti dan variabel pengetahuan mendeteksi kekeliruan dan audit tenure penggunaannya masih belum banyak dari penelitian terdahulu tentang audit judgment. Pengetahuan mendeteksi kekeliruan inginn dikembangkan peneliti dari variabel pengetahuan. Audit judgment dapat memengaruhi suatu pendapat atau opini yang akan dikeluarkan oleh auditor. Karena itulah, masih diperlukannya penelitian mengenai audit judgment.

Perilaku individu yang mampu dipengaruhinya pembuatan audit judgment banyak menarik perhatian akademisi ataupun praktisi akuntansi. Walupun demikian, semakin meningkat perhatian tersebut tidak diimbangi adanya pertumbuhan penelitian dibidang akuntansi perilaku, dimana banyaknya penelitian hal tersebut justru tidak menjadi fokus utama Meyer(dalam Yustrianthe,2012). Berdasarkan latar belakang yang telah dipaparkan diatas, maka pokok permasalahannya adalah : Apakah pengalaman audit, pengetahuan mendeteksi kekeliruan, independensi dan audit tenure berpengaruh pada audit judgment. Adapun tujuan dari penelitian ini adalah : Untuk mendapatkan bukti empiris pengaruh pengalaman audit, pengetahuan mendeteksi kekeliruan, independensi dan audit tenure pada audit judgment.

Pengalaman audit dapat memperdalam dan memperluas kemampuan kerja auditor sehinga auditor akan mampu belajar aktif dan peka dalam tugas auditnya dan menunjang pemberian judgment yang tepat. Pengalaman yang dimiliki seorang 
ISSN: 2302-8556

auditor juga dapat menambah pengetahuannya mengenai pendeteksian kekeliruan dan memberikan keahlian dan ketrampilan dalam bekerja sehingga dapat menunjang judgment yang diambil oleh auditor. Pernyataan diatas didukung oleh (Indira,2016) menyatakan bahwa auditor yang berpengalaman selain mempunyai kemampuan dalam mnemukan kecurangan atau kekeliruan tentunya ia akan mampu memberikan keakurasian yang lebih pada penjelasan dibandingkan dengan auditor yang kurang berpengalaman. Choo (1991) menyatakan auditor memiliki pengalaman yang lebih akan menemukan banyak hal yang tidak lazim dibandingkan auditor yang kurang memiliki pengalaman, oleh karena itu mampu dipengaruhinya audit judgment yang dibuat auditor. Hal ini diperkuat Putri (2015), Reni Yendrawati (2015) dan Tielman (2012) yang membuktikan secara empiris audit judgment dipengaruhi positif oleh pengalaman auditor.

$\mathrm{H}_{1} \quad$ : Pengalaman Audit berpengaruh positif pada audit judgment

Auditor yang mempunyai pengetahuan yang baik maka auditor akanlebih mudah memahami kemungkinan adanya kekeliruan dalam auditnya. Karena itulah, akan lebih efektif dan efisien pada proses pengauditannya dan juga nantinya akan mendapatkan kualitas hasil audit yang baik. Auditor yang memiliki tingkat pengetahuan yang tinggi, akan mempunyai pandangan yang lebih luas mengenai berbagai hal, salah satunya pengetahuan mendeteksi kekeliruan. Hal diatas diperkuat oleh penelitian Seni Fitriani dan Daljono(2012), Arleen Herwaty (2009), Desiana (2012) dan Christanti (2016) memberikan bukti dipengaruhi positif audit judgment dari pengetahuan mendeteksi kekeliruan. 
$\mathrm{H}_{2} \quad$ : Pengetahuan Mendeteksi Kekeliruan berpengaruh positif pada audit judgment.

Independensi merupakan salah satu sikap yang sangat penting dimiliki oleh auditor. Pada hal ini auditor bekerja dalam keadaan bebas dari pengaruh pihak manapun. Auditor yang bersikap independen, dapat dihasilkannya audit judgment yang akurat serta dapat dipercayai oleh publik dan semakin baik kinerjanya. Handani (2014) menyatakan auditor yang memiliki independensi yang tinggi maka kinerjanya akan lebih baik dan dapat menghasilkan ketepatan pemberian opini yang lebih baik pula. Pernyataan ini diperkuat oleh Handni (2014) dan Muklis (2010) dan Julia (2015) menemukan hasil bahwa dipengaruhinya positif audit judgment oleh independensi. Selain itu juga didukung oleh De Angelo (1981) menyatakan independensi adalah hal yang penting selain kemampuan teknik auditor.

$\mathrm{H}_{3} \quad$ : Independensi berpengaruh positif pada audit judgment.

Anggaran waktu audit merupakan sebagai elemen yang sangat dibutuhkan untuk mengkontrol suatu KAP dan mekanisme operasional. Semakin cepat auditor melaksanakan program audit, akan semakin kecil biaya yang dikeluarkan untuk pelaksanaan program audit. Keberadaan tekanan waktu ini dapat memicu auditor bertindak tidak etis. Namun, apabila dapat mengalokasikan waktu dengan tepat justru dapat berfungsi sebagai mekanisme kontrol auditor dalam tugasnya. Dalam hal ini auditor dapat menggunakan teknik audit yang baik dan tepat sehingga auditor dapat memusatkan dirinya pada penyelesaian tugasnya. Pernyataan tersebut diperkuat dengan penelitian Sofiani dan Tjondro (2014) menyatakan adanya pengaruh yang 
ISSN: 2302-8556

signifikan positif antara audit tenure terhadap audit judgment. Syahrin (2016) menunjukan audit tenure berpengaruh signifikan positif terhadap audit judgment, karena semakin banyaknya tekanan dari waktu untuk seorang auditor maka auditor tersebut haruslah cepat untuk menyelesaikan tugas auditnya.

$\mathrm{H}_{4} \quad$ : Audit Tenure berpengaruh positif pada audit judgment

Penelitian ini membahas mengenai hubungan pengalaman audit, pengetahuan mendeteksi kekeliruan, independensi dan audit tenure pada audit judgment, sehingga kerangka konseptual hubungan antar vaiabel dalam penelitian ini sebagai berikut:

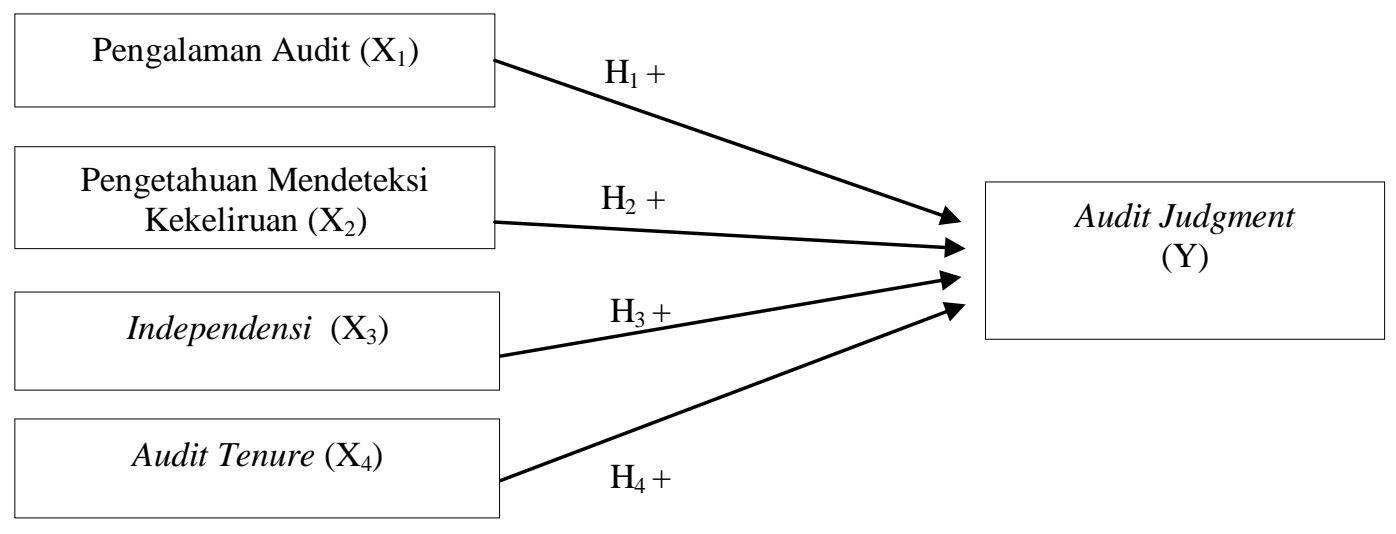

\section{Gambar 1. Kerangka Konseptual Penelitian}

\section{METODE PENELITIAN}

Lokasi penelitian ini dilakukan yakni Kantor Akuntan Publik di Bali. KAP yang terpilih adalah anggota Ikatan Akuntan Publik Indonesia dan terdaftar dalam Derektorat Kantor Akuntan Publik Indonesia. Obyek dalam penelitian ini adalah faktor-faktor yang mempengaruhi audit judgment yaitu pengalaman audit, pengetahuan mendeteksi kekeliruan, independensi, dan audit tenure pada auditor 
yang bekerja di KAP yang merupakan anggota IAPI tahun 2017. Variabel terikatt (Y) penelitian ini yakni audit judgment. Audit judgment merupakan suatu dasar penilaian auditor dari pertimbangan ataspersepsi dalam menanggapi informasilaporan keuangan yang diperoleh dan ditambah dengan faktor dalam diri seorang auditor.

Variabel bebas $(\mathrm{X})$ penelitian ini yaitu pengalaman audit $\left(\mathrm{X}_{1}\right)$, pengetahuan mendeteksi kekeliruan $\left(\mathrm{X}_{2}\right)$, independensi $\left(\mathrm{X}_{3}\right)$, audit tenure $\left(\mathrm{X}_{4}\right)$. Pengalaman adalah suatu proses penambahan berkembangnya potensi untuk bertingkah laku baik dan proses pembelajaran dari pendidikan nonformal maupun formal. Dalam audit, pembuatan perencanaan audit yang efektif dibutuhkan pengetahuan tentang banyaknya pola-pola yang berhubungan dengan adanya kemungkinan kekeliruan pada laporan keuangan. Independensi merupakan sikap auditor yang tidakdipengaruhi oleh pihak-pihak yang berkepentingann dalam memberikan pendapat serta tegas dalam mengambil keputusan. Audit tenure adalah kondisi adanya anggaran dan batasan waktu yang diberikan oleh auditor, sehingga dapat mempengaruhi judgment yang ia buat dan kinerjanya.

Skor yang dihasilkan dari jawaban kuesioner masing-masing responden merupakan data kuantitatif yang digunakan oleh peneliti. Daftar KAP di Bali yang masih aktif dan terdaftar di direktori IAPI tahun 2017 wilayah Bali merupakan data kualitatif. Hasil jawaban atau kuesioner yang diperoleh dari responden merupakan data primer penelitian ini. Populasi penelitian ini yakni auditor yang bekerja pada KAP di wilayah Bali yang terdaftar dalam IAPI 2017. Jumlah auditor yang menjadi populasi sebanyak 76 orang. Purposive sampling digunakan sebagai teknik penentuan 
ISSN: 2302-8556

E-Jurnal Akuntansi Universitas Udayana

Vol.23.3.Juni (2018): 2175-2202

sampel pada penelitian ini. Metode pengumpulan data yang digunakan adalah kuesioner. Hasil dari kuesioner diukur menggunakan skala Likert 6 poin sebagai berikut.

\section{Tabel 1.}

Daftar Skala Likert

\begin{tabular}{clc}
\hline No & \multicolumn{1}{c}{ Uraian } & Skor \\
\hline 1 & Sangat Tidak Setuju & 1 \\
2 & Tidak Setuju & 2 \\
3 & Kurang Setuju & 3 \\
4 & Setuju & 4 \\
5 & Cukup Setuju & 5 \\
6 & Sangat Setuju & 6
\end{tabular}

Sumber: Data Diolah, 2017

Penelitian ini menggunakan teknis analisis regresi linear berganda yang diolah menggunakan aplikasi stastitical package for social science (SPSS). Persamaan regresi dalam penelitian ini adalah :

$$
Y=a+\beta_{1} X_{1}+\beta_{2} X_{2}+\beta_{3} X_{3}+\beta_{4} X_{4}+e
$$

\section{Keterangan:}

$\begin{array}{ll}\mathrm{Y} & =\text { Audit Judgment } \\ \mathrm{a} & =\text { Konstanta atau titik perpotongan dengan sumbu Y,bila X=0 } \\ \beta_{1}-\beta_{4} & =\text { Koefisien Regresi } \\ \mathrm{X}_{1} & =\text { Pengalaman Audit } \\ \mathrm{X}_{2} & =\text { Pengetahuan Mendeteksi Kekeliruan } \\ \mathrm{X}_{3} & =\text { Independensi } \\ \mathrm{X}_{4} & =\text { Audit Tenure } \\ \mathrm{e} & =\text { Standar Error }\end{array}$

\section{HASIL DAN PEMBAHASAN}

Kuesioner yang disebar penelitian ini sebanyak 76 eksemplar ke tuju KAP di Bali. Kuesioner yang dikembalikan sebanyak 54 kuesioner oleh responden dan hanya 44 
kuesioner yang telah diperiksa serta dapat digunakan oleh peneliti, karena telah memenuhi kriteria.

\section{Tabel 2.}

\section{Perincian Pengembalian dan Penggunaan Kuesioner}

\begin{tabular}{lc}
\hline \multicolumn{1}{c}{ Uraian } & Jumlah Kuesioner \\
\hline Total Kuesioner yang disebar & 76 \\
Kuesioner yang dikembalikan & 54 \\
Kuesioner yang gugur & 10 \\
Kuesioner yang digunakan & 44 \\
Tingkat Pengembalian (response rate) $=54 / 76 \times 100 \%$ & $71 \%$ \\
Tingkat Penggunaan (usable respon rate) $=44 / 76 \times 100 \%$ & $58 \%$ \\
\hline
\end{tabular}

Sumber : Data diolah, 2017

\section{Tabel 3.}

Hasil Statistik Deskriptif

\begin{tabular}{lccccc}
\hline \multicolumn{1}{c}{ Variabel } & N & Minimum & Maximum & Mean & Std Deviation \\
\hline Pengalaman Audit $\left(\mathrm{X}_{1}\right)$ & 44 & 15,00 & 30,00 & 24,2500 & 4,58067 \\
Pengetahuan Mendeteksi & 44 & 15,00 & 30,00 & 24,2727 & 4,58696 \\
Kekeliruan $\left(\mathrm{X}_{2}\right)$ & & & & & \\
Independensi $\left(\mathrm{X}_{3}\right)$ & 44 & 18,00 & 36,00 & 29,4545 & 5,59258 \\
Audit Tenure $\left(\mathrm{X}_{4}\right)$ & 44 & 18,00 & 36,00 & 29,5682 & 5,86038 \\
Audit Judgment $(\mathrm{Y})$ & 44 & 18,00 & 36,00 & 29,2273 & 5,99559 \\
\hline
\end{tabular}

Sumber : Data Diolah, 2017

Variabel audit judgment $(\mathrm{Y})$ memiliki nilai minimum 18,00, nilai maksimum 36,00, mean 29,2273 dan standar deviasi 5,99559. Ini berarti terjadi perbedaan nilai audit judgment yang diteliti terhadap nilai rata-rata sebesar 5,99559. Mean 29,2273 dengan jumlah 6 pernyataan dalam kuesioner yang dikaitkan dengan skala likert enam poin dengan hasil 4,87. Oleh karena itu, rata-rata responden yang dihasilkan memiliki audit judgment judgment yang akurat. 
ISSN: 2302-8556

Variabel pengalaman audit $\left(\mathrm{X}_{1}\right)$ memiliki nilai minimum 15,00 , nilai maksimum 30,00, mean 24,2500 dan standar deviasi 4,58067. Berarti terjadi perbedaan nilai pengalaman audit terhadapnilai rata-ratanya sebesar 4,58067. Mean 24,2500 dengan jumlah 5 pernyataan dalam kuesioner yangdikaitkan dengan skala likert enam poin didapatkannya hasil 4,90. Oleh karena itu, rata-rata responden yang dihasilkan memiliki pengalaman yang lebih.

Variabel pengetahuan mendeteksi kekeliruan $\left(\mathrm{X}_{2}\right)$ nilai minimum 15,00 , nilai maksimum 30,00, mean 24,2727 dan standar deviasi 4,58696. Berarti perbedaannilai pengetahuan mendeteksi kekeliruan terhadap nilai rata-rata sebesar 4,58696. Mean 24,2727 dengan jumlah 5 pernyataan dalam kuesioner yang dikaitkan dengan skala likert enam poin didapatkannya hasil 4,85. Oleh karena itu, rata-rata responden yang dihasilkan memiliki pengetahuan mendeteksi kekeliruannya yang baik.

Variabel independensi $\left(\mathrm{X}_{3}\right)$ nilai minimum 18,00, nilai maksimum 36,00, mean 29,4545 dan standar deviasi 5,59258. Berarti terjadi perbedaan nilai independensi terhadap nilai rata-rata sebesar 5,59258. Mean 29,4545 dengan jumlah 6 pernyataan dalam kuesioner yangdiakitkannya dengan skala likert enam poin didapatkannya hasil 4,90. Oleh karena itu, rata-rata responden yang dihasilkan memiliki independensi yang kuat.

Variabel audit tenure $\left(\mathrm{X}_{4}\right)$ nilai minimum 18,00 , nilai maksimum 36,00 , mean 29,5682 dan standardeviasi 5,86038. Berarti terjadi perbedaan nilai audit tenure terhadap nilai rata-rata sebesar 5,86038. Mean 29,5682 dengan jumlah 6 pernyataan dalam kuesioner yang dikaitkan dengan skala likert enam poin didapatkannya hasil 
4,92. Oleh karena itu, rata-rata responden yang dihasilkan memiliki audit tenure yang baik.

Hasil uji normalitas mengindikasikan bahwa nilai Asymp.Sig,(2-tailed) 0,200 lebih besar dari 0,05 bahwa model persamaan regresi tersebut berdistribusi normal. Hasil uji multikolinearitas bahwa nilai VIF dan tolerance dari variabel pengalaman audit, pengetahuan mendeteksi kekeliruan, independensi dan audit tenure dinyatakan hasil nilai tolerance untuk setiap variabel $\geq 0,10$ dan nilai VIF $\leq 10$ yang memiliki arti bebasnya model persamaan regresi dari multikolinearitas. Memperoleh nilai signifikansi masing-masing variabel bebas nilainya melebihi 0,05 yang justru telah menunjukkan bebasnya model regresi dari gejala heteroskedastisitas.

\section{Tabel 4.}

Analisis Regresi Linear Berganda

\begin{tabular}{lccc}
\hline \multicolumn{1}{c}{ Keterangan } & Nilai Beta & Signifikasi & Hipotesis \\
\hline (Constant) & $-5,556$ & 0,003 & - \\
Pengalaman Audit & 0,277 & 0,002 & $\mathrm{H}_{1}$ diterima \\
Pengetahuan Mendeteksi & 0,330 & 0,000 & $\mathrm{H}_{2}$ diterima \\
Kekeliruan & & & \\
Independensi & 0,338 & 0,000 & $\mathrm{H}_{3}$ diterima \\
Audit Tenure & 0,325 & 0,000 & $\mathrm{H}_{4}$ diterima
\end{tabular}

R Square $=0,806$

Adjust R Square $=0,786$

Sig. $\mathrm{F}=0,000$

Sumber : Data diolah 2017

$$
Y=-5,556+0,277 X_{1}+0,330 X_{2}+0,338 X_{3}+0,325 X_{4}
$$

Nilai konstanta sebesar -5,556 mengandung arti bahwa apabila seorang auditor tidak memiliki pengalaman audit, pengetahuan mendeteksi kekeliruan, independensi dan audit tenure dalam tugas auditnya maka sikap auditor akan menurun dalam menghasilkan audit judgment. 
ISSN: 2302-8556

Dilihat pada Tabel 4 bahwa variabel pengalaman audit $\left(\mathrm{X}_{1}\right)$ diketahui nilai signifikansi 0,002 dengan nilai koefisien regresi $\left(\beta_{1}\right)$ bernilai positif sebesar 0,277 , maka $\mathrm{H}_{1}$ dapat diterima. Artinya pengalaman audit memiliki pengaruh positif pada audit judgment. Tingginya pengalaman auditor dapat meningkatkannya keakuratan audit judgment. Hal ini dikarenakan seiring meningkatnya pengalaman yang dimiliki auditor maka akan mengasah keahlian auditnya sehingga audit judgment yang dihasilkan akan semakin baik. Sebaliknya pengalaman auditor semakin rendah dapat dihasilkannya audit judgment yang rendah. Auditor yang pengalaman auditnya rendah maka cenderung rendah dalam melakukan penilaian. Hal ini dikarenakan auditor yang kurang berpengalaman belum memiliki kemampuan dan pengetahuan yang cukup, sehingga penilaian mereka kalah akurat denganauditor yang berpengalaman.

Sesuai dengan teori pengambilan keputusan menyatakan bahwa pada suatu situasi yang sedang dihadapi seseorang bertindak hanya berdasarkan persepsinya karena ia memiliki keterbatasan pengetahuan. Berdasarkan asumsi tersebut, bahwa tiap individu dapat memiliki struktur pengetahuan, pengalaman dan pendidikan yang berbeda dan kondisi ini akan memengaruhi bagaimana carasuatu keputusan tersebut dibuat. Melalui pengalamannya, auditor akan mampu belajar aktif dalam pengauditan, sehingga dapat menunjang ketepatan judgment.

Hasil penelitian ini mendukung dengan penelitian Putri (2015), Reni Yendrawati (2015) dan Tielman (2012) yang dibuktikannya bahwa dipengaruhinya 
positif audit judgment oleh pengalaman audit. Dilihat pada Tabel 4 bahwa variabel pengetahuan mendeteksi kekeliruan $\left(\mathrm{X}_{2}\right)$ diketahui nilai signifikansi 0,000 dengan nilai koefisien regresi $\left(\beta_{2}\right)$ bernilai positif sebesar 0,330 , maka $\mathrm{H}_{2}$ dapat diterima. Artinya pengetahuan mendeteksi kekeliruan memiliki pengaruh positif pada audit judgment. Tingginya pengetahuan mendeteksi kekeliruan auditor dapat meningkatkannya keakuratan audit judgment. Tingkat pengetahuan yang auditor miliki dapat memengaruhi keputusannya ketika dalam pembuatan audit judgment dan juga dapat sebagai keefektifan kerja auditor. Oleh karena itulah, tingkat pengetahuan menjadi suatu hal yang penting dalam proses audit judgment.Sebaliknya semakin rendah pengetahuan mendeteksi kekeliruan auditor dapat merendahkan hasil audit judgment. Pengetahuan yang rendah pada seseorang akan mempengaruhi pandangan, tanggapan dan kemampuannya tentang informasi yang terdapat dalam laporankeuangan sehingga auditor tidak mampu memberikan respon yang memadai dan mengakibatkan rendahnya penilaian dalam mengambil keputusan pada audit judgment .

Teori pengambilan keputusan menyatakan bahwa pada suatu situasi yang sedang dihadapi seseorang bertindak hanya berdasarkan persepsinya karena ia memiliki keterbatasan pengetahuan. Asumsi tersebut, bahwa tiap individu dapat memiliki struktur pengetahuan, pengalaman dan pendidikan yang berbeda dan kondisi ini memengaruhi bagaimana carasuatu keputusan tersebut dibuat. Pengetahuan yang auditor miliki maka akan mampu belajar aktif dalam menghadapi 
ISSN: 2302-8556

tugasnya, mengolah informasi yang relevan, dan berinteraksi sosial pada lingkungan kerjanya, sehingga dapat menunjang ketepatan judgment.

Hasil penelitian ini mendukungnya penelitian dari Seni Fitriani (2012), Arleen Herawaty (2009), Desiana (2012) dan Christanti (2016) yang menemukan bahwa audit judgment yang dihasilkan auditor dipengaruhinya positif oleh pengetahuan mendeteksi kekeliruan.

Dilihat pada Tabel 4 bahwa variabel independensi $\left(\mathrm{X}_{3}\right)$ diketahui nilai signifikansi 0,000 dengan nilai koefisien regresi $\left(\beta_{3}\right)$ bernilai positif sebesar 0,338 , maka $\mathrm{H}_{3}$ dapat diterima. Artinya independensi memiliki pengaruh positif pada audit judgment. Tingginya independensi seorang auditor dapat meningkatkan semakin akuratnya audit judgment. Seorang auditor yang bersikap independen, maka dapat dihasilkannya audit judgment yang dapat dipercayai oleh banyak pihak dan masyarakat. Selain itu, dapat bekerja dengan lebih baik dan menjadi meningkat kinerjanya. Sebaliknya semakin rendah independensi auditor dapat menghasilkan audit judgment yang rendah. Sikap independensi yang tidak dijaga oleh auditor akan menghasilkan laporan auditan sebagai hasil akhir pekerjaanya tidaksesuai dengan keadaan sesungguhnya. Bahkan dapat menjadi keraguan sebagai dasar pengambilan keputusan dan nantinya menyebabkan tidak dapat dipercayanya atas hasil auditnya. Karena itulah, cenderung tidak mampu menghasilkan audit judgment yang akurat.

Sesuai dengan teori atribusi, faktor internal (atribusi internal) dan faktor eksternal (atribusi eksternal) dapat memengaruhi perilaku dari seseorang. Karena 
itulah pengaruh perilaku seseorang inilah yang menyebabkan auditor menjadi berlaku independen atau sebaliknya. Jadi auditor harus tetap mempertahankan independensi yang tinggi dalam melakukan proses pengauditan, maka tidak aka nada kesulitan bagi auditor untuk mampu menjalankan tugasnya dan menentukan ketepatan judgment dalam menghasilkan suatulaporan auditan sehingga hasil auditnya dapat dipercaya. Hasil penelitian ini mendukung daripenelitian Handani (2014) dan Mukhlis (2010) dan Julia (2015) menunjukkan bahwa audit judgment dipengaruhi positif pada independensi.

Dilihat pada Tabel 4 bahwa variabel audit tenure $\left(\mathrm{X}_{4}\right)$ diketahui nilai signifikansi 0,000 dengan nilai koefisien regresi $\left(\beta_{4}\right)$ bernilai positif sebesar 0,325, maka $\mathrm{H}_{4}$ dapat diterima. Artinya audit tenure memiliki pengaruh positif pada audit judgment. Audit tenure semakin tinggi dapat meningkatkannya keakuratan audit judgment. Audit tenure dapat mempengaruhi kinerja seseorang. Audit tenure dikondisikan anggaran waktu dan batasan waktu dalam mengaudit. Hal ini mengindikasikan pada adanya penugasan yang diberikan,seorang auditor telah dialokasikannya waktu yang sesuai dengan kompleksitas tugas maka auditor harus mampu melaksanakan tugas yang diberikan secara mudah.Apabila terjadi permasalahan tekanan waktu pada auditor, justru ia merespon dengan positif yakni menjalankan tugasnya dengan baik pada batasan waktu yang telah diberikan. Sebaliknya semakin rendah audit tenure pada auditor dapat menghasilkan audit judgment yang rendah. Hal ini dikarenakan apabila terlalu lamanya pengalokasian 
ISSN: 2302-8556

waktu tentu akan lebih banyakmelamun dan tidak termotivasinya untuk lebih giat dan aktif seorang auditor saat melakukan pekerjaan sehingga judgment yang dihasilkan kurang berkualitas dan jangka waktu penyelesaian audit akan lebih panjang serta tidak dapat menyelesaikan tugasnya tepat waktu.

Sesuai dengan teori penetapan tujuan yang menegaskan bahwa untuk memperoleh kinerja yang lebih baik harus adanya tujuan yang menantang, sulit,dan lebih spesifik dibandingkan dengan tidak jelasnya suatu tujuan. Auditor harus memiliki sebuah penetapan tujuan, hal ini diperlukan berkaitan dengan audit tenure dimana kondisi auditor diberikan batasan dan anggaran waktu audit. Dengan demikian, apabila adanya waktu penyelesaian audit yang ketat dapat menjadi stimulus sehingga diharapkan auditor merespon tekanan waktu audit dengan baik dan termotivasi agar bersikap fokus untuk menyelesaikan tugas auditnya. Oleh sebab itu, dengan tepat waktu laporan keuangan auditan dapet diselesaikan dan hal yang direncanakan berjalan sesuai atas tujuan awal yang telah disepakati. Semakin meningkat audit tenure, maka auditor akan menggunakan waktu sebaik-baiknya sehingga semakin meningkat pula melakukan auditjudgment.

Hasil penelitian ini mendukung hasil penelitian Sofiani dan Tjondro (2014) menunjukkan adanya pengaruh yang signifikan positif antara audit tenure terhadap audit judgment. Serta diperkuat dengan penelitian dari Syahrin (2016) menunjukan audit tenure berpengaruh signifikan positif terhadap audit judgment, karena semakin banyaknya tekanan dari waktu untuk seorang auditor maka seorang auditor tersebut haruslah cepat untuk menyelesaikan tugas auditnya. 


\section{SIMPULAN}

Berdasarkan latar belakang, landasan teori, metodelogi penelitian dan hasil pembahasan analisi data yang dapat ditarik beberapa kesimpulan yaitu seorang auditor harus menambah pengalaman serta keahlian yang dimilikinya, juga harus meningkatkan pengetahuan mendeteksi kekeliruan, mampu mempertahankan dan meningkatkan independensi yang dimilikinya dan dapat meningkatkan audit tenure agar dihasilkan audit judgment yang akurat.

Berdasarkan hasil penelitian dan kesimpulan diatas, maka saran yang dapat diberikan adalah sebagai berikut: Manajemen KAP disarankan mengkombinasikan auditor yang sudah berpengalaman dan auditor yang belum berpengalaman dalam Tim Audit. Auditor junior dan auditor senior diperlukan melakukan dan difasilitasi mengenai forum diskusi seperti diskusi terfokus dalam group (Focus Group Disscusition) untuk sharing pengetahuan dan pengalamannya (khususnya tentang audit lapangan) yang dimiliki auditor, dimana hal ini yang perlu dilakukan oleh manajemen KAP. Karena hal inilah yang menyebabkan lebih meningkatnya audit judgment yang dihasilkan auditor. Saat mengeluarkan lima opini audit, diharapkan auditor senantiasa untuk me-reviu kembali mengenai kondisi penyebab auditor dalam mengeluarkan lima opini audit tersebut. Auditor disarankan untuk mempertahankan integritasnya dengan meningkatkan independensinya. Bagi auditor harus memiliki profesionalisme yang tinggi agar dapat meningkatkan pengalaman dalam audit, meningkatkan pengetahuan yang dimilikinya, meningkatkan independensi dan audit tenure sehingga dapat menghasilkan audit judgment yang akurat. Manajemen KAP 
ISSN: 2302-8556

E-Jurnal Akuntansi Universitas Udayana

Vol.23.3.Juni (2018): 2175-2202

diharapkan untuk mengalokasikan waktu yang disesuaikan dengan kompleksitas tugas dan terus memotivasi auditor untuk mengoperasionalkan waktu sebaik mungkin dengan cara memusatkan dirinya pada penyelesaian pekerjaan. Bagi peneliti selanjutnya diharapkan dapat memperluas populasi penelitian sehingga hasil penelitian ini nantinya dapat digeneralisasikan untuk seluruh auditor di Indonesia.

\section{REFERENSI}

Arleen Herawaty \& Yulius Kurnia Susanto.2009. Pengaruh Profesionalisme, Pengetahuan Mendeteksi Kekeliruan, dan Etika Profesi Terhadap Pertimbangan Tingkat Materialitas Akuntan Publik. Jurnal. Trisakti School of Management.

Ashton, H. R dan J. Jennedy. 2002. Eliminating Recency with Self Review : Case of Auditor Going Concern Judgment. Journal of behavioral decision making., 3: 221-231.

Choo, F. dan K.T. Trotman. 1991. The Relationship Between Knowledge Structure and Judgments for Experience and Inexperience Auditors. The Accounting Review. Juli.p.464-485.

Christanti, Made Puspita. 2016. Pengaruh Pengalaman Auditor, Locus of Control dan Pengetahuan Mendeteksi Kekeliruan Pada Audit Judgment (Studi Empiris Pada Kantor Akuntan Publik di Bali). Skripsi. Fakultas Ekonomi dan Bisnis Universitas Udayana. Denpasar.

Cohen, Jeffrey R., Lisa Milici Gaynor, Ganesh Krishnamoorthy, and Arnold M. Wright.2011. The Impact on Auditor Judgments of CEO Influence on Audit Committee Independence. Auditing:A Journal Of Practice \& Theory. Vol. 30, No.4

D. Frederick dan R. Libby. 1990. Experience and the ability to explain findings. Journal of Accounting Research 28:348-367

De Angelo, L.E. 1981. Auditor Independence, "Low Balling", and Disclosure Regulation. Journal of Accounting and Economics, 3(2) :113-127. 
Desiana. (2012). Pengaruh Profesionalisme, Pengetahuan Mendeteksi Kekeliruan, dan etika Profesi Terhadap Pertimbangan Tingkat Materialitas oleh Auditor pada KAP di Surabaya. Berkala Ilmiah Mahasiswa Akuntansi Vol. 1 No. 1.

Enofe, A.O, C.J. Mgbame, P.O. Okpako and E.N. Atube. 2013. The Impact Of Auditor Age On Auditor Independence. Research Journal of Finance and Accounting. University of Benin P.M.B. 1154, 11(5):121-150. Benin City, Edo State, Nigeria.

Gibbins, M. (1984). Propositions about the psychology of professional judgment in public accounting. Journal of Accounting Research, 22(1), 103-125.

Honglin Fu, Hun-Tong Tan, and Jixun Zhang. 2011. Effect of Auditor Negotiation Experience and Client Negotiating Style on Auditors' Judgments in an Auditor-Client Negotiation Context. Auditing: A Journal of Practice \& Theory. Vol.30, No.3, pp. 225-237. American Accounting Association.

Indira Biksa, Ida Ayu. 2016. Pengaruh Pengalaman, Independensi, Skeptisisme Profesional Auditor Pada Pendeteksian Kecurangan. Skripsi. Fakultas Ekonomi dan Bisnis Universitas Udayana. Denpasar.

Iskandar, T. M and Zuraidah, M. S. 2011. Assesing The Effects Of Self-Efficacy And Task Complexity On Internal Control Audit Jugdment. Asian Academy of Management. Universitas Sains Malaysia. AAMJAF. Vol. 7. No. 1. 29- 52, 2011.

Johari, Razana Juhaida, Zuraidah Mohd Sanusi, Yusarina Mat Isa dan Aziatul Waznah Ghazali. 2014. Comparative judgment of novice and expert on internal control task: assessment on work effort and ethical orientation. Accounting Research Institute and Faculty of Accountancy. 145, 352-360. UITM Shah Alam, 40450 Shah Alam, Selangor, Malaysia.

Julia, Drupadi. 2015. Pengaruh Keahlian Auditor, Tekanan Ketaatan, dan Independensi Pada Audit Judgment. Jurnal Ilmiah Akuntansi dan Bisnis.Universitas Udayana, Denpasar.

Lee, H-Y, V. Mande \& M.Son. 2009. Do Lengthy Auditor Tenure and The Provision of Non-audit Services by The External Auditor Reduce Audit Report Lags? International Journal of Auditing. Vol 13,pp. 87-104.

Libby, R. 1995. The Role of Knowledge and Memory in Audit judgment. In Judgment and Decision-Making Research in Accounting and Auditing, edited 
ISSN: 2302-8556

E-Jurnal Akuntansi Universitas Udayana

Vol.23.3.Juni (2018): 2175-2202

by R. Ashton, and A. Ashton. pp. 176-206. Cambridge University Press. New York

Lopa, Nur Azizah Arief. 2014. Pengaruh Tekanan Ketaatan, Kompleksitas Tugas Dan Pengalaman Kerja Auditor Pada Pertimbangan Audit. Skripsi Universitas Hasanuddin, Makasar.

Maharani, Adisti Putri. 2014. "Pengaruh Audit Tenure, Audit Fee, Rotasi Auditor dan Spesialisasi Auditor Terhadap Kualitas Audit”. Naskah Publikasi. Universitas Muhammadiyah Surakarta.

Martinov. dan Pflugrath. 2008. The Strength of an Accounting Firm's Ethical Environment and The Quality of Auditors' Judgment. Australia: Springers. 87: 237-253.

Mayasari, Dian. 2011. "Pengaruh Profesionalisme, Independensi, Kompetensi, Etika Profesi dan Pengetahuan Auditor dalam Mendeteksi Kekeliruan Terhadap Ketepatan Pemberian Opini Audit oleh Auditor (Studi Empiris Pada Kantor Akuntan Publik di Jakarta". Skripsi S1 Universitas Islam Negreri Syarif Hidayatullah. Jakarta.

Mukhlis, Jamhuri Akil. 2010. Pengaruh Pengalaman Audit, Independensi Auditor, dan Kode Etik Pada Audit Judgment. Skripsi Universitas Negeri Syarif Hidayatullah, Jakarta.

Mulyadi. 2008. Sistem akuntansi, Penerbit Salemba Empat, Jakarta.

Nadhiroh, Siti Asih. 2010. Pengaruh Kompleksitas Tugas, Orientasi Tujuan, dan SelfEfficacy Terhadap Kinerja Auditor Dalam Pembuatan Audit Judgement (Studi Pada Kantor Akuntan Publik di Semarang), Skripsi Fakultas Ekonomi pada Universitas Diponegoro Semarang.

Pranoto, Anita .2013. Pengaruh kompleksitas tugas, tekanan ketaatan, pengalaman audit, dan pengetahuan auditor dalam Pertimbangan audit. Undergraduate thesis. Widya Mandala Catholic University Surabaya.

Putri, Febrina Prima. 2015. Pengaruh Pengetahuan Auditor, Pengalaman Auditor, Kompleksitas Tugas, Locus Of Control, dan Tekanan Ketaatan Terhadap Audit Judgment. Jurnal Fakultas Ekonomi. Universitas Riau. Pekanbaru. 
Reni, Yendrawati. 2015. Pengaruh Gender, Pengalaman Auditor, Kompleksitas Tugas, Tekanan Ketaatan, Kemampuan Kerja dan Pengetahuan Auditor Terhadap Audit Judgement. Jurnal Inovasi Dan Kewirausahaan, Fakultas ekonomi Universitas Islam Indonesia.

Seni Fitriani dan Daljono. (2012). Pengaruh Tekanan Ketaatan, Kompleksitas Tugas, Pengetahuan dan Persepsi Etis Terhadap Audit Judgement. Diponegoro Journal of Accounting. Volume 1 no.1 Tahun 2012.

Shelton, Sandra Waller. 1999. The Effect of Experience on The Use Of Irrelevent Evidence In Auditor Judgment. The Accounting Review. Vol 74. No.2

Sofiani, Maria Maghdalena Oerip Liana. Tjondro, Elisa.2014. Pengaruh Tekanan Ketaatan, Pengalaman Audit dan Audit Tenure Terhadap Audit Judgement. Tax and Accounting Review, Vol.4, No.1.Universitas Kristen Petra.

Sucipto, Andre. 2007. Analisis Pengaruh Pengetahuan dan Pengalaman terhadap Kemampuan Akuntan Pemeriksa dalam Mendeteksi Kekeliruan pada KAP di Surabaya. Thesis. Universitas Petra Surabaya.

Syahrin, Annisa Febrina. 2016. Pengaruh Tekanan Ketaatan, Pengalaman Audit, Gender dan Audit Tenure Terhadap Audit Judgment (Studi Kasus Kantor Akuntan Publik Jakarta Barat). Skripsi. Fakultas Ekonomi dan Bisnis Universitas Mercu Buana, Jakarta.

Tielman, Elisabeth Mariana Andita. 2012. Pengaruh Tekanan Ketaatan, Tekanan Anggaran Waktu, Kompleksitas Tugas, Pengetahuan dan Pengalaman Auditor pada Audit Judgment. Skripsi. Jurusan Akuntansi pada Fakultas Ekonomi dan Bisnis Universitas Diponegoro, Semarang.

Wright, Arnold M., and Sally Wright, 2014. Modification Of The Audit Report: Mitigating Investor Attribution by Disclosing the Auditor's Judgment Process. Behavioral Research in Accounting. Vol.26, No.2, pp.35-50. America Accounting Association.

Yustrianthe, Rahmawati Hanny. 2012. Beberapa Faktor Yang Mempengaruhi Audit Judgment Auditor Pemerintah. Jurnal Dinamika Akuntansi. Vol. 4 No. 2 September 2012. pp. 72-82. 